\title{
Improving employee productivity through work engagement: Empirical evidence from higher education sector
}

\author{
Jalal Hanaysha*
}

Senior Lecturer, DRB-Hicom University of Automotive Malaysia, Malaysia

\begin{tabular}{l}
\hline C H R O N I C L E \\
\hline Article history: \\
Received June 5, 2015 \\
Received in revised format \\
August 162015 \\
Accepted November 282015 \\
Available online \\
November 282015 \\
\hline Keywords: \\
Employee engagement \\
Employee productivity \\
Educational sector
\end{tabular}

\section{Introduction}

Improving employee productivity has been one of the most important objectives for several organizations. This is because higher levels of employee productivity provide an organization and its employees with various advantages. For instance, higher productivity leads to favourable economic growth, large profitability and better social progress (Sharma \& Sharma, 2014). Additionally, employees who are more productive can obtain better wages/ salaries, better working conditions, and favourable employment opportunities. Moreover, higher productivity tends to maximize organizational competitive advantage through cost reductions and improvement in high quality of output (Baily et al., 2005; Hill et al., 2014; Wright, 2004). All of these benefits have made employee productivity worthy of attention. Therefore, looking at its antecedents is very important to ensure organizational survival and long term success.

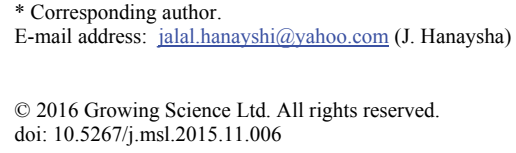


Markos and Sridevi (2010) demonstrated that employers should consider investing in workforce engagement, because recent researches on this topic have clearly indicated that there was a positive association between work engagement and performance outcomes, such as employee retention and productivity. Certain scholars (Richman, 2006; Fleming \& Asplund, 2007) added that employees who are engaged or involved with their jobs are perceived to be more productive because they are motivated toward accomplishing their work beyond any personal factors. They are also more focused than those of disengaged counterparts. Furthermore, employees who are engaged are in most cases assumed to work more efficiently and with the aim of putting the success of the organization in their minds as a top priority.

Although several researches have emphasized about the significance of employee work engagement in driving performance and positive business outcomes, there are only few empirical evidences to support such claims (Saks, 2006). It is also noted that engagement should to be considered as a key organizational strategy that involves all the levels of an organization (Frank et al., 2004). Saxena and Srivastava (2015) reported that work engagement has become one of the main challenges/activities that need to be well managed to fulfil organization objectives. They also demonstrated that there is a need to test its effect on performance outcomes.

In fact, the issue of employee productivity has recently emerged in the literature and carries extreme significance. For instance, previous research works surrounding the topic of employee productivity in service contexts have been largely neglected (Brown et al., 2009; Filitrault et al., 1996). As such, the definition of employee productivity has been hard to conceptualize and measure. For instance, the common definition of productivity has mainly emphasized on the ratio between input costs and output value, despite existing associated implications that it could depend on the nature of business. Overall, there appears to be an ambiguity in conceptualizing, measuring, and testing the antecedents of employee productivity. Hence, this study aims to test the effect of work engagement on employee productivity in Malaysian higher education sector to cover existing gaps in the literature. The next section presents the literature review concerning previous research on employee productivity and work engagement. It also explains the possible link between both variables.

\section{Literature Review}

\subsection{Employee Productivity}

One of the key issues that most organizations face nowadays is the need to improve employee productivity. Employee productivity is an assessment of the efficiency of a worker or group of workers. In actual terms, productivity is a component which directly affects the company's profits (Gummesson, 1998; Sels et al., 2006). Productivity may be evaluated in terms of the output of an employee in a specific period of time. Typically, the productivity of a given worker will be assessed relative to an average out for employees doing similar work. It can also be assessed according to the amount of units of a product or service that an employee handles in a defined time frame (Piana, 2001). As the success of an organization relies mainly on the productivity of its employees, therefore, employee productivity has become an important objective for businesses (Cato \& Gordon, 2009; Gummesson, 1998; Sharma \& Sharma, 2014).

Many studies have focused on one or two ways to measure productivity and since many different approaches are taken, it can be challenging to compare the results (Nollman, 2013). Overall, there is a lack of an effective and standardized way to assess productivity. According to Sharma and Sharma (2014), employee productivity is based on the amount of time that an employee is physically present at his/ her job, besides the extent to which he/ she is "mentally present" or efficiently working during the presence at the job. Companies should address such issues in order to ensure high worker productivity. Ferreira and Du Plessis (2009) indicated that productivity can be evaluated in terms of the time spent 
by an employee actively executing the job he or she was hired to do, in order to produce the desired outcomes expected from an employee's job description.

Previous literature has clearly discussed the advantages of employee productivity which would lead to organizational success. According to Sharma and Sharma (2014), higher productivity results in economic growth, higher profitability, and social progress. It is only by increasing productivity, employees can obtain better wages/ salaries, working conditions and larger employment opportunities. Cato and Gordon (2009) also demonstrated that the alignment of the strategic vision to employee productivity is a key contributor to the success of an organization. This alignment as a result would motivate and inspire employees to be more creative, and this ultimately can improve their performance effectiveness to accomplish organizational goals and objectives (Morales et al., 2001; Obdulio, 2014). Moreover, higher productivity tends to increase the competitive advantage through reduction in costs and improvement in quality of output.

The above discussion has clearly discussed the concept of employee productivity. It indicates that employee productivity is a key determinant of organizational profitability and success. In the following section, work engagement as key human resource practice and its effect on employee productivity is presented.

\subsection{Work Engagement}

Employee work engagement is one of the main business priorities for organizational executives. According to McEwen (2011), engagement depends on employees' perceptions and evaluations of their working experience, including their employer, organizational leaders, the job itself, and work environment. Echols (2005) advised that in order to enhance employee engagement, managers should pay attention to the skills, knowledge and talents of their staff. The author added that when employees are aware of their strengths and talents, their level of engagement will be higher, and this ultimately leads to better performance. Rothmann and Storm (2003) demonstrated that work engagement can be reflected through the energy, behavioural satisfaction, efficacy and involvement. Swaminathan and Rajasekaran (2010) also concluded that engagement results from employee satisfaction and work motivation.

Several definitions of employee engagement exist in the literature. Fleming and Asplund (2007, p. 2) describes employee engagement as, "the ability to capture the heads, hearts, and souls of your employees to instil an intrinsic desire and passion for excellence". Certain scholars also viewed employee engagement as a construct which consists of cognitive, emotional, and behavioural elements that are related to the role of employee performance (Shuck et al., 2011). It reflects the commitment and involvement of an employee towards his/ her work that is aimed to improve organizational performance (Sundaray, 2011). Furthermore, Bakker and Demerouti (2008) defined engagement as "a positive, fulfilling, work-related state of mind that is characterized by Vigor, dedication, and absorption".

According to Bakker and Demerouti (2008), Vigor can be described in terms of an employee's levels of energy and the mental resilience while doing his her work. Shirom (2003) indicated that Vigor refers to the mental and physical health of an employee. On the other hand, Harpaz and Snir (2014) expressed dedication in terms of being highly involved in the work and is reflected through the feelings of enthusiasm, challenge, and significance. The other dimension of work engagement which is known as absorption was previously described by being fully focused and happily attached in one's work, whereby the employee feels that time passes quickly and has difficulties with detaching himself from work (Truss et al., 2013). 
Employee engagement is a key organizational issue that should be strictly given enormous consideration by organizational management in the current scenario of challenging business environment (Saxena \& Srivastava, 2015). This is because highly engaged and motivated employees reflect the core values of the organization, and this resultantly reinforces overall brand equity (Ramanujam, 2014). The review of literature reveals that engaged employees yield positive organizational outcomes. In the rapidly changing markets, business leaders recognize that highly engaged employees can increase their productivity and firm performance (Bakker \& Demerouti, 2008; Markos \& Sridevi, 2010). In other words, engaged employees feel passionate about their work, happy to work in their organization, and have the enthusiasm to go to their work every day (Ramanujam, 2014). Besides that, employees who are engaged in their work are deemed very important for their organizations in maintaining competitive advantages; coping with changes, and ensuring work innovations.

Past studies (Abraham, 2012; Anitha, 2014; Echols, 2005; Haid \& Sims, 2009) found that work engagement had a significant positive effect on employee productivity. According to Zahargier and Balasundaram (2011), a successful and highly productive business can be achieved by engaging its employees in improving their performance. Similarly, Harter et al. (2002) conducted a meta-analysis of data on 7,939 business units from 36 firms that represent different sectors and found out employee engagement had a significant positive impact on increased productivity. In line with the study of Markos and Sridevi (2010), employers should consider investing in workforce engagement because it has a positive impact on performance outcomes such as employee productivity. Based on the above discussion, the following hypotheses are presented:

$\mathrm{H}_{1}$ : Vigor has positive effect on employee productivity.

$\mathrm{H}_{2}$ : Dedication has positive effect on employee productivity.

$\mathrm{H}_{3}$ : Absorption has positive effect on employee productivity.

$\mathrm{H}_{4}$ : Overall work engagement has positive effect on employee productivity.

\section{Methodology}

This study followed the quantitative approach for collecting the relevant data from respondents. In particular, an online survey was administered to 870 administrative and academic staff at public universities in northern Malaysia. The measurement scales of constructs were adopted and adapted

from previous studies to ensure that the respondents can easily understand them and suit the context of this study. As stated above in the literature review, work engagement is composed of three dimensions, namely Vigor, dedication, and absorption. All of the aforementioned dimensions were measured using the scale developed by Schaufeli and Bakker (2003); Vigor (three items), dedication (five items), and absorption (four items). Furthermore, employee productivity was measured using five items taken from the studies of Chen and Tjosvold (2008); Lee and Brand (2010). All the items were measured on fivepoint Likert scale ranging from " $1=$ strongly disagree" to " $5=$ strongly agree".

The collected data was analysed on structural equation modelling (SEM) using AMOS 18. A number of tests such as Cronbach's alpha reliability, convergent validity, face validity, factor analysis, and regression were conducted to generate the outcomes of this study. The measurement model incorporating the resulting re-specified scales is then subjected to confirmatory factor analysis. After that, the structural model was assessed for model fit and to test the individual hypotheses. Structural equation modelling is used due to its strengths in yielding accurate and reliable results. According to Chin (1998), SEM is flexible in modelling the relationships between predictors and criterion variables. Additionally, SEM is the preferred method to test causal relationships between any two or more variables making it easy to articulate research hypothesis (Gunzler et al., 2013). 


\section{Analysis of Results}

The results of respondents' profile are presented in Table 1. As it can be been in the table, 65 (26.9\%) of the participants are male, while $177(73.1 \%)$ are female. On age profile, the majority of the participants $(50 \%)$ belong to the age group of 26 to 35 years old, followed by the age of 36 to 45 years that is represented by $21 \%$. Those whose ages between 18 and 25 years accounted for $2.9 \%$ of total response, and only $16(6.6 \%)$ were 46 years and above. In terms of education, this study has $36(14.9 \%)$ holders of diploma, $79(32.6 \%)$ staff who have undergraduate degree, $125(51.7 \%)$ with postgraduate certificate, and $2(0.8 \%)$ with acquire other certificates. The majority of respondents $(69 \%)$ had more than 5 years of working experience.

Table 1

Respondents' Profile

\begin{tabular}{llcc}
\hline & Category & Frequency & Percent \\
\hline \multirow{2}{*}{ Gender } & Male & 65 & 26.9 \\
& Female & 177 & 73.1 \\
\cline { 2 - 4 } & Total & 242 & 100 \\
\hline \multirow{2}{*}{ Age } & $18-25$ years & 7 & 2.9 \\
& $26-35$ years & 121 & 50 \\
& $36-45$ years & 98 & 40.5 \\
\hline Qualification & 46 years and above & 16 & 6.6 \\
& Diploma & 36 & 14.9 \\
& Undergraduate & 79 & 32.6 \\
& Master & 74 & 30.6 \\
& Doctorate & 51 & 21.1 \\
Work experience & Others & 2 & 0.8 \\
& 1 year - 2 years & 23 & 9.5 \\
& Between 2 years and 5 years & 40 & 16.5 \\
& More than 5 years & 167 & 69 \\
\hline
\end{tabular}

Moreover, the reliability analysis was conducted on all variables using Cronbach's alpha. The findings revealed that the Cronbach's alpha values are satisfactory ranging from 0.755 to 0.882 . Specifically, employee engagement achieved a Cronbach's alpha value of 0.882 . The dimensions of employee engagement were also reported at high reliability Cronbach's alpha; Vigor (0.812), dedication (0.867), absorption (0.758). Similarly, employee productivity recorded a Cronbach's alpha value of 0.755 . Therefore, it can be concluded that the values of Cronbach's alpha for all variables are acceptable and satisfied the minimum requirement as suggested by Pallant (2007).

Factor analysis was also conducted on all variables to ensure that each set of items are measuring what they are supposed to measure. It was also conducted to ensure the existence of convergent and content validity. As all the measures were adapted from previous studies, confirmatory factor analysis (CFA) instead of exploratory factor analysis (EFA) is done. The procedure for conducting the analysis was done using AMOS 18 through the measurement model which comprises all items together in one model. The results indicated that the factor loading for all items ranged from 0.48 to 0.86 (see Appendix A). Based on these results, it can be said that all items achieved the recommended value as suggested by Hair el al. (2010). Therefore, factor analysis is satisfactory for all constructs.

After ensuring acceptable factor loadings for all items using the measurement model, the structural model was then drawn. The main purpose of structural model is to ensure the goodness of model fit through a number of criterion values. As it can be seen in Fig. 1, the structural model achieved a reasonable fit for the data. Specifically, the value of Chi-square is equal to 282.875. Other fit criterions $(\mathrm{df}=129, \mathrm{GFI}=0.888, \mathrm{AGFI}=0.851, \mathrm{TLI}=0.899, \mathrm{CFI}=914$, and RMSEA $=0.070)$ were also used to provide further support for the chi-square and ensure that the assumptions of model fit are achieved. From these results, it can be concluded that the model reasonably fit the data. 


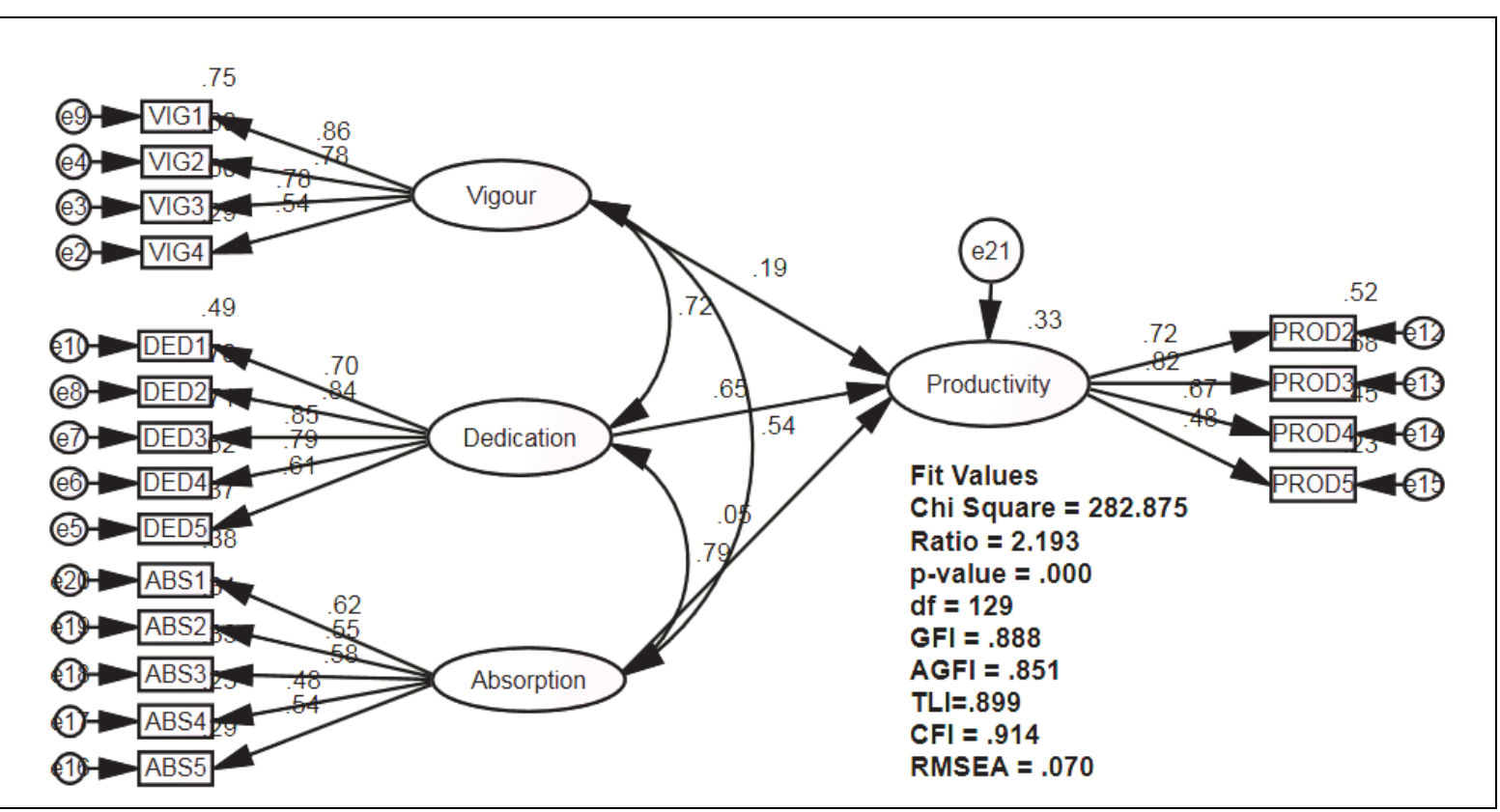

To test the hypotheses of this study, the regression table which was generated from structural model was used. As shown in Table 2, all of the hypotheses are supported. Specifically, H1 which states that Vigor has positive effect on employee productivity is confirmed $(\beta=0.192$, $t$-value $=2.219, p<0.05)$. The findings also reveal that dedication has positive effect on employee productivity, the relation is statistically significant and positive $(\beta=0.653$, $\mathrm{t}$-value $=2.806, \mathrm{p}<0.05)$, therefore, $\mathrm{H} 2$ is accepted. Moreover, the positive effect of absorption on employee productivity is supported ( $\beta=0.051$, $t$-value $=3.025, \mathrm{p}<0.05)$, Hence, H3 is accepted. Finally, the results indicate that overall work engagement has significant positive effect on employee productivity $(\beta=0.354$, t-value $=4.565, p<0.05)$, therefore, $\mathrm{H} 4$ is supported. Overall, this study found that employee engagement explains $33 \%$ of overall variance in employee productivity.

Table 2

Research Findings

\begin{tabular}{llccccc} 
& \multicolumn{1}{c}{ Hypothesized Effect } & Std. Beta & S.E. & C.R. & P & Support \\
\hline H1: & Vigor has positive effect on employee productivity. & 0.192 & 0.062 & 2.219 & 0.001 & Yes \\
H2: & Dedication has positive effect on employee productivity. & 0.653 & 0.140 & 2.806 & 0.005 & Yes \\
H3: & Absorption has positive effect on employee productivity. & 0.051 & 0.104 & 3.025 & $* * *$ & Yes \\
H4: & $\begin{array}{l}\text { Overall work engagement has positive effect on employee } \\
\text { productivity. }\end{array}$ & 0.354 & 0.078 & 4.565 & $* * *$ & Yes \\
\hline
\end{tabular}

\section{Discussion and Conclusion}

The rationale of this study was to examine the effect of work engagement and its dimensions on employee productivity at public universities in northern Malaysia. The findings indicated that work engagement has a significant positive effect on employee productivity. It is also found that all dimensions of employee engagement (vigor, dedication, and absorption) have significant positive effects on employee productivity. The result was supported by previous studies which reported that work engagement plays an important role in driving employee productivity. Markos and Sridevi (2010) 
demonstrated that employees who are not engaged at their workplaces are most likely to waste their times on tasks that have low priority and fail to show their full commitment to do their tasks. Moreover, a number of studies reported that engaged employees tend to exhibit emotional job attachment and higher productivity (Abraham, 2012; Shuck et al., 2011).

Overall, this study provides empirical evidence that work engagement has a significant positive effect on employee productivity. Therefore, employers should put sufficient emphasis on work engagement and frequently evaluate the progress of their employees to ensure the welfare of their organizations. Besides, employers across public educational institutions are advised to conduct frequent surveys from time to time to clearly understand the level of work engagement among their employees and their satisfaction about work environment. Such activities would enable them to develop the suitable strategies for overcoming any issue. For example, the acquisition of talents is a good strategy to ensure effective recruitment. Moreover, providing sufficient resources those including financial, physical, or materials are necessary to reinforce employee productivity. It is also suggested that employers should adopt the two-way communication strategy between them and their employee to allow the employee share some ideas about their jobs and any issues that may affect their productivity. With such emphasis, it is believed that employee will be more engaged in their works and have higher inspiration to be productive.

Although the current study has presented some useful insights into the causal relationship between work engagement and employee productivity, it can be acknowledged that there are some limitations and suggestions to be considered in future researches. First, the participants of this study are only limited to administrative and academic staff working at the public universities in northern Malaysia. This may hinder the generalizability of the findings of this study to other industry contexts. Therefore, future research should replicate this study by sampling employees from different industries with larger sample sizes. Second, this study has relied on a cross-sectional design where the data was collected from participants using survey method. Given this limitation, it is suggested that future research should investigate the antecedents of employee productivity using longitudinal research designs and methodologies. Finally, this study examined only one antecedent to employee productivity, hence, future research is suggested to test the effect of other human resource practices on employee productivity such as work specialization and leadership style.

\section{References}

Abraham, S. (2012). Job satisfaction as an antecedent to employee engagement. SIES Journal of Management, 8(2), 27-36.

Anitha J. (2014). Determinants of employee engagement and their impact on employee performance. International Journal of Productivity and Performance Management, 63(3), 308-323.

Baily, M. N., Farrell, D., Greenberg, E., Henrich, J. D., Jinjo, N., Jolles, M., \& Remes, J. (2005). Increasing global competition and labor productivity: Lessons from the US automotive industry. McKensie Global Institute, November, 7.

Bakker, A. B., \& Demerouti, E. (2008). Towards a model of work engagement. Career Development International, 13(3), 209-223.

Brown, J., Elliott, S., Christensen-Hughes, J., Lyons, S., Mann, S., \& Zdaniuk, A. (2009). Using human resource management (HRM) practices to improve productivity in the Canadian tourism sector. Electronic Article, University of Guelph, 1-15.

Cato, S. T., \& Gordon, J. (2009). Relationship of the strategic vision alignment to employee productivity and student enrolment. Research in Higher Education Journal, 7, 1-20.

Chen, Y., \& Tjosvold, D. (2008). Collectivist values for productive teamwork between Korean and Chinese employees. Working Paper Series, Centre for Asian Pacific Studies. Accessed on 19 June, 2015 from: http://commons.ln.edu.hk/cgi/viewcontent.cgi?article=1002\&context=capswp

Chin, W. W. (1998). Issues and opinion on structural equation modeling. MIS Quarterly, 22(1), 7-16. 
Echols, M. E. (2005). Engaging Employees to Impact Performance. Chief Learning Officer, 4(2), 4448.

Ferreira, A., \& Du Plessis, T. (2009). Effect of online social networking on employee productivity. South African Journal of Information Management, 11(1), 1-11.

Filitrault, P., Harvey J. \& Chebat, J.C., Service quality and service productivity management practice. Industrial Marketing Management, 25(3), 1996, 243-255.

Fleming, J.H., \& Asplund, J. (2007). Human Sigma. New York; Gallup Press.

Frank, F. D., Finnegan, R. P. \& Taylor, C. R. (2004). The race for talent: retaining and engaging workers in the 21 st century. Human Resource Planning, 27(3), 12-25.

Gummesson, E. (1998). Productivity, quality and relationship marketing in service operations. International Journal of Contemporary Hospitality Management, 10(1), 4-15.

Gunzler, D., Chen, T., Wu, P., \& Zhang, H. (2013). Introduction to mediation analysis with structural equation modeling. Shanghai Archives of Psychiatry, 25(6), 390-394.

Haid, M., \& Sims, J. (2009). Employee engagement: Maximizing organizational performance. Leadership Insights.

Hair, J. F., Jr., Black, W. C., Babin, B. J., Anderson, R. E., \& Tatham, R. L. (2010). Multivariate Data Analyisis $\left(7^{\text {th }}\right.$ edition) Upper Saddle River, N.J: Pearson Prentice Hall.

Harpaz, I., \& Snir, R. (2014).Heavy Work Investment: Its Nature, Sources, Outcomes, and Future Directions. Routledge.

Hill, C., Jones, G., \& Schilling, M. (2014). Strategic management: theory: an integrated approach. Cengage Learning.

Lee, S. Y., \& Brand, J. L. (2010). Can personal control over the physical environment ease distractions in office workplaces? Ergonomics, 53(3), 324-335.

Markos, S., \& Sridevi, M. S. (2010). Employee engagement: The key to improving performance. International Journal of Business and Management, 5(12), 89-96.

McEwen, D. (2011). Employee Engagement: A Systemic Approach to High Employee Engagement. Available at:

http://www.cgnglobal.com/sites/default/files/Employee_Engagement_CGN\%20Global.pdf

Morales, C., Cory, C., \& Bozell, D. (2001).A comparative efficiency study between a live lecture and a Web-based live-switched multi-camera streaming video distance learning instructional unit. Proceedings of the 2001 Information Resources Management Association International Conference, Toronto, Ontario, Canada, 63-66.

Nollman, M. R. (2013). Sustainability Initiatives in the Workplace and Employee Productivity (Master Thesis), Southern Illinois University Carbondale.

Obdulio, D. L. (2014). How management can improve corporate culture in order to have an effective work environment. Trade Publication, 75(8), 14.

Piana, V. (2001). Productivity. Retreived on $4^{\text {th }}$ September, 2015 from: http://www.economicswebinstitute.org/glossary/prdctvt.htm

Rothmann, S., \& Storm, K. (2003). Work Engagement in the South African Police Service. Available at: http://www.sajip.co.za/index.php/sajip/article/view/925/973.

Ramanujam, N. (2014). Fostering productivity, organizational effectiveness via employee engagement. Retrieved on 13 August, 2015 from: http://insights.wired.com/profiles/blogs/fostering-productivityorganizational-effectiveness-via-employee?xg_source=msg_appr_blogpost\#axzz3iewHyaaO.

Saks, A. M. (2006). Antecedents and consequences of employee engagement. Journal of managerial psychology, 21(7), 600-619.

Saxena, V., \& Srivastava, R. K. (2015). Impact of employee engagement on employee performanceCase of manufacturing sectors. International Journal of Management Research and Business Strategy, 4(2), 139-174.

Schaufeli, W. B., \& Bakker, A. B. (2003). Utrecht work engagement scale: Preliminary manual. Occupational Health Psychology Unit, Utrecht University, Utrecht. 
Sels, L., De Winne, S., Delmotte, J., Maes, J., Faems, D., \& Forrier, A. (2006). Linking HRM and small business performance: An examination of the impact of HRM intensity on the productivity and financial performance of small businesses. Small Business Economics, 26(1), 83-101.

Sharma, M. S., \& Sharma, M. V. (2014).Employee Engagement to Enhance Productivity in Current Scenario. International Journal of Commerce, Business and Management, 3(4), 595-604.

Shirom, A. (2003). Feeling Vigorous at work? The construct of Vigor and the study of positive affect in organizations, in Ganster, D. and Perrewe, P.L. (Eds). Research in Organizational Stress and Well-being, JAI Press, Greenwich, CT, 135-65.

Shuck, M. B., Rocco, T. S. \& Albornoz, C. A. (2011). Exploring employee engagement from the employee perspective: implications for HRD. Journal of European Industrial Training, 35(4), 300325.

Sundaray, B. K. (2011). Employee Engagement: A Driver of Organizational Effectiveness. European Journal of Business and Management, 3(8), 53-59.

Swaminathan, J., \& Rajasekaran, D. (2010). Essential Components of Employee Engagement - A Study with Reference to TNSTC, Kumbakonam. Advances in Management, 3(12), 55-59.

Truss, C., Alfes, K., Delbridge, R., Shantz, A., \& Soane, E. (2013). Employee engagement in theory and practice. Routledge.

Wright, A. (2004). Reward management in context. CIPD Publishing.

Zahargier, M. S., \& Balasundaram, N. (2011).Factors affecting Employeesee Performance in Readyaide Garments (RMGs) Sector in Chittagong, Bangladesh. Economic Sciences, 63(1), 9-15.



(C) 2016 by the authors; licensee Growing Science, Canada. This is an open access article distributed under the terms and conditions of the Creative Commons Attribution (CC-BY) license (http://creativecommons.org/licenses/by/4.0/). 


\section{Appendix A}

Measurement Scale of Items

\begin{tabular}{|c|c|c|}
\hline Code & Construct/ Item & $\begin{array}{c}\text { Factor } \\
\text { Loading }\end{array}$ \\
\hline & Work Engagement & \\
\hline & a. Vigor $($ Cronbach's Alpha $=0.812)$ & \\
\hline VIG1 & At this institution, I feel energetic to do my work. & 0.86 \\
\hline VIG2 & At this institution, I feel strong and capable to do my work. & 0.78 \\
\hline VIG3 & When I get up in the morning, I feel like going to work. & 0.78 \\
\hline \multirow[t]{2}{*}{ VIG4 } & I can continue working for very long period at a time. & 0.54 \\
\hline & b. Dedication (Cronbach's Alpha $=0.867)$ & \\
\hline DED1 & I find the work that I do full of meaning and purpose. & 0.70 \\
\hline DED2 & I am enthusiastic about my job. & 0.84 \\
\hline DED3 & My job inspires me. & 0.85 \\
\hline DED4 & I am proud on the work that I do. & 0.79 \\
\hline \multirow[t]{2}{*}{ DED5 } & To me, my job is challenging. & 0.61 \\
\hline & c. Absorption (Cronbach's Alpha $=0.758)$ & \\
\hline ABS1 & Time flies when I'm working. & 0.62 \\
\hline ABS2 & When I am working, I forget everything else around me. & 0.55 \\
\hline ABS3 & I feel happy when I am working intensely. & 0.58 \\
\hline ABS4 & I have a lot of work to do everyday & 0.48 \\
\hline \multirow[t]{2}{*}{ ABS5 } & It is difficult to separate myself from my job. & 0.54 \\
\hline & Employee Productivity (Cronbach's Alpha = 0.755) & \\
\hline PROD1 & I do a large amount of work each day & 0.49 \\
\hline PROD2 & I accomplish tasks quickly and efficiently. & 0.72 \\
\hline PROD3 & I have a high standard of task accomplishment. & 0.82 \\
\hline PROD4 & My work outcomes are of high quality. & 0.67 \\
\hline PROD5 & I always beat our team targets. & 0.48 \\
\hline
\end{tabular}

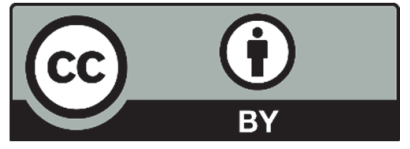

(C) 2016 by the authors; licensee Growing Science, Canada. This is an open access article distributed under the terms and conditions of the Creative Commons Attribution (CC-BY) license (http://creativecommons.org/licenses/by/4.0/). 